\title{
Folk først i helsesektoren
}

\author{
Venstre vil særlig løfte frem fem helsepolitiske temaer ved høstens valg: 1. Et godt offentlig helsevesen \\ som sikrer likeverdig tilgang til helsetjenester og styrket pasientsikkerhet. 2. Forebygging og tidlig hjelp. \\ 3. Bedre psykisk helsehjelp i kommunene. 4. Mindre byråkrati - helsepersonell skal få mer tid til å drive \\ pasientbehandling. 5. Mer politisk styring av sykehusene.
}

Mye går bra i norsk helsevesen. Det jobber mange dyktige, engasjerte mennesker i helsesektoren. Likevel er det en del utfordringer og systemfeil som vi må ta tak $\mathrm{i}$, både for å bedre behandlingen av den enkelte pasient, for å lette arbeidshverdagen til helsearbeidere og for å styrke den politiske styringen. Venstre vil sette folk først i helsesektoren.

Venstre mener at frislipp av private aktører vil undergrave det offentlige helsevesenet på sikt. Først og fremst frykter vi en kompetanseflukt fra det offentlige. Venstre har i stedet tro på at det offentlige kan bli smartere og dermed få unna flere køer. For Venstre er det essensielt at det offentlige helsevesenet tilbyr så god kvalitet og har så god ressurstilgang at det ikke oppstår et klasseskille når det gjelder helsetjenester.

Det brukes over 100 milliarder årlig på spesialisthelsetjenesten. Leger og sykepleiere bruker mindre tid på pasientrettet arbeid og mer tid foran PC-en. Det går på bekostning av pasientbehandling. En del pasientgrupper opplever lange ventelister, og vi ser fortsatt eksempler på korridorplasser, dårlig tilgjengelighet, feil ved innkallingsrutiner osv. Det må vi gjøre noe med, men ikke ved å undergrave det offentlige helsevesenet.

En annen utfordring er sosial ulikhet $i$ helse. Vi vet at det er enklere for ressurssterke pasienter å få oppfylt sine rettigheter enn svakere grupper, som pasienter med rus- og psykiatriproblemer. En fast kontaktperson til alle som innlegges, må innføres snarest. Det må også sørges for bedre informasjon om pasientrettigheter, slik at pasienter fra ulike sosiale lag får samme behandling like raskt.

Venstre vil korte ned på ventelistene ved å la helsepersonell få mer tid til å drive pasientbehandling. Blant tiltakene er kutt i byråkratiet og flere helsesekretærer som avlaster legene. Venstre har også foreslått en forenklingskommisjon som gjennomgår antall resultatmål, lover, forskrifter og regelverk med mål om å redusere unødig byråkrati. I tillegg må det bli implementert nasjonale standarder for IKT-systemer.

\section{Styrket helsetilbud i folks nærmiljø} Frem til 1950-årene var smittsomme sykdommer vår største helseutfordring. I dag er det de ikke-smittsomme sykdommene som fyller legekontorer og sykehus. Både fastleger, helsesøstre og helsestasjoner gjør en

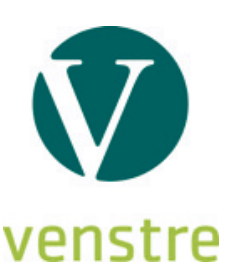

viktig jobb med forebygging. Venstre vil derfor gi fastlegene et bredere ansvar for å følge pasienten, opprette flere fastlegehjemler og ansette 1000 nye helsesøstre over fire år.

Forebygging handler imidlertid også om den mentale helsen. Ifølge Folkehelseinstituttet er psykiske lidelser hovedårsak til omtrent en tredel av alle uførepensjoner. Tallet er sannsynligvis høyere, fordi mange med psykiske lidelser innvilges uføretrygd for ikke-psykiske lidelser.

Da er det uholdbart at det ved utgangen av 2012 sto over 9000 voksne og 3400 barn i kø for å få psykiatrisk hjelp i Norge. Venstre mener dagens kø gjør at små psykiske problemer blir store, alvorlige og livstruende. En godt utbygd førstelinjetjeneste i kommunene kan forhindre at små problemer får utvikle seg til å bli store. Det er grunn til å tro at mange problemer som havner i spesialisthelsetjenesten, ville blitt løst i førstelinjetjenesten dersom det var et godt utbygd tilbud i kommunene. Dette er samfunnsøkonomisk ulønnsomt, i tillegg til at det forringer livskvaliteten til det enkelte mennesket. Venstre vil derfor styrke primærhelsetjenesten, ikke bare for somatiske lidelser, men også for psykisk helse. Lavterskeltilbud med høy kvalitet i folks nærmiljø vil ikke bare gi stor menneskelig gevinst, det vil sannsynligvis også være samfunnsøkonomisk lønnsomt.

\section{Mer politisk styring i stort, mindre i smått}

Venstre mener at foretaksmodellen har svakheter med tanke på ansvarsfordeling og byråkratisering. Derfor ønsker vi en utredning om alternativ organisering. $\mathrm{Vi}$ legger imidlertid ikke ned en modell før vi har andre gode alternativer. De har vi ikke ennå.

For å styrke den politiske styringen ønsker Venstre at Stortinget skal vedta en rullerende nasjonal helseplan som definerer og konkretiserer sykehusstrukturen, behandlingstilbudet og de overordnede prioriteringene i helsevesenet. Vi vil flytte mer makt og flere avgjørelser fra helseforetakene ned til det enkelte sykehus. Videre vil vi øke andelen av rammefinansiering til helseforetakene, for å gi foretakene et mer helhetlig ansvar.

\section{Rebekka Borsch \\ rebekka@venstre.no}

Rebekka Borsch (f. 1976) er stortingskandidat for Buskerud Venstre og sentralstyremedlem i Venstre.

Mottatt 20.6.2013 og godkjent 27.6.13. Medisinsk redaktør Hanne Støre Valeur. 